\title{
CHARACTERIZATION OF GARDEN SOIL POLLUTION IN THE MINING VILLAGE OF STRATONI, N GREECE
}

\author{
Argyraki A. ${ }^{1}$, Plakaki A. ${ }^{1}$, and Godelitsas A. ${ }^{2}$ \\ ${ }^{\prime}$ National and Kapodistrian University of Athens, Faculty of Geology and Geoenvironment, \\ Department of Economic Geology and Geochemistry,argyraki@geol.uoa.gr, \\ angeliki_plakaki@hotmail.com \\ ${ }^{2}$ National and Kapodistrian University of Athens, Faculty of Geology and Geoenvironment, \\ Department of Mineralogy and Petrology, agodel@geol.uoa.g
}

\begin{abstract}
Complete characterization of soil pollution in sulphide ore mining areas can assist risk assessment because the potential human health risk from chemical species intake is related not only to the total content of elements in soil but also to the type of bounding of elements to solid phases and their solubility. The methodology of this study included a combination of chemical analysis and mineralogical determination of surface soil samples from house gardens and communal country spaces in a mining village of north Greece. The content of soil $\mathrm{Pb}, \mathrm{Zn}, \mathrm{Cu}, \mathrm{Cd}, \mathrm{Fe}$ and $\mathrm{Mn}$ was determined by sequential extraction with 5 operational stages and subsequent measurement by AAS. The produced chemical data were coupled by XRD and SEM-EDS mineralogical analysis. Results show variety of solid phases withholding the metals, thus differentiation of metal mobility/ availability in the environment. Lead has high mean concentration of $1090 \mu \mathrm{g} \mathrm{g}^{-1}$ but is fractioned mostly (53\%) in the residual phase of less soluble soil components limiting its potential bioavailability. Zinc, Cd and $\mathrm{Mn}$ with means of $878 \mu \mathrm{g} \mathrm{g}^{-1}, 6 \mu \mathrm{g} \mathrm{g}^{-1}$ and $4465 \mu \mathrm{g} \mathrm{g} \mathrm{g}^{-1}$ respectively, participate in appreciable proportion (5-25\%) in easily extractable phases indicating easy mobilization and greater potential bioavailability.
\end{abstract}

Key words: heavy metals, geochemistry, sequential extraction, soil mineralogy.

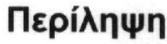

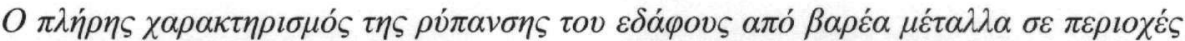

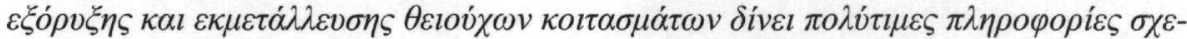

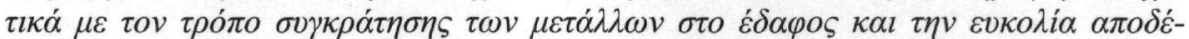

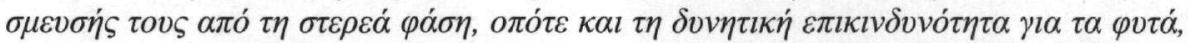

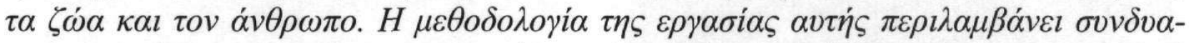

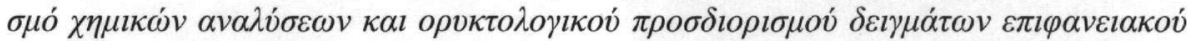

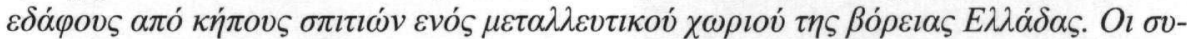

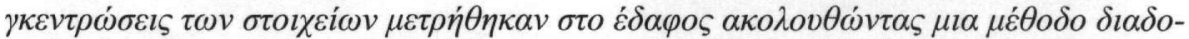

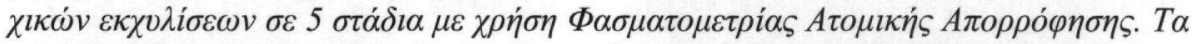

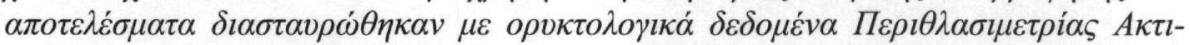

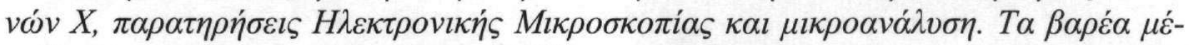

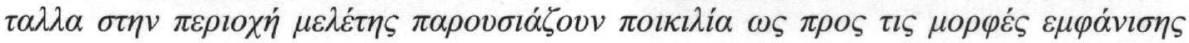




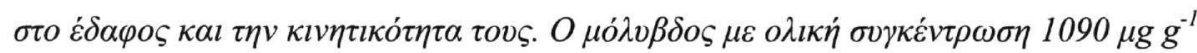

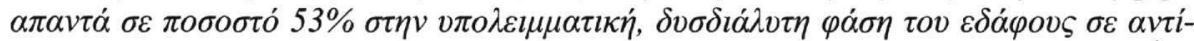

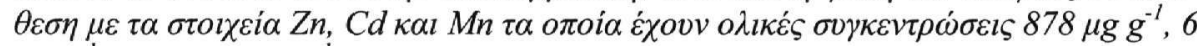

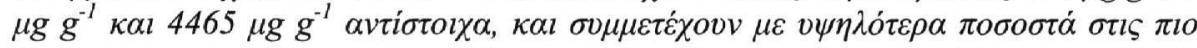

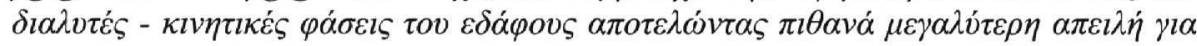

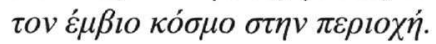

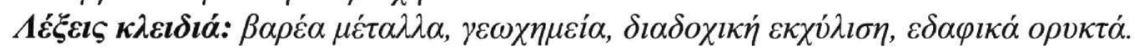

\section{Introduction}

The surface earth environment is characterized by redistribution of chemical elements and significant interactions within the system rock-soil-water-air-life. In sulphide ore mining and industrial areas, soil is usually enriched in heavy metals due to both natural weathering of metalliferous minerals and anthropogenic influences. The latter, through mining and associated mineral processing activities, may cause increased dispersion and exposure of contaminants derived from natural sources with health implications to humans and animals. However, the occurrence alone of elevated concentrations of heavy metals in the environment does not indicate there is a significant risk as this will depend on a number of factors including their chemical form, concentration, bioavailability, the size of the mineral particles in which the elements occur, the extend of exposure and the dose received (Appleton 1995). Thus, very high concentrations may not pose a health risk as the element may be in a mineral or chemical form that is relatively immobile, insoluble in water and not taken up by plants or by humans and animals if ingested. Conversely, some elements become more available in acid waters and soils and may therefore be taken up by plants or mobilized and transported in surface and groundwater.

Soil has a central role as a sink and an exposure pathway of pollution to humans and animals in heavy metal contaminated sites (Thornton 1993, Abrahams and Steigmajer 2003, Kelepertsis and Bibou 1991, Vardaki and Kelepertsis 1999). Surface soil may receive heavy metals through the processes of fluvial, gravitational and atmospheric dispersion. Significant pollution pathways include inhalation of wind-blown dust and ingestion of contaminated food and water. In entering the food chain, soil characteristics such as organic matter content, $\mathrm{pH}$, Eh, clay and iron content, affect mobility of heavy metals and hence their availability to growing plants and crops (Appleton 1995, Kabata -Pendias and Pendias 1984). Also, direct ingestion of contaminated soil and dust is believed to be a major way of transfer of potentially harmful elements into humans. Several scientific studies worldwide have provided strong evidence that especially young children are prone to ingest relatively large amounts of contaminated dust or dirt indirectly from contamination on their hands (Clausing et al. 1987, Watt et al. 1993). It follows that detailed characterization of surface soil in metal mining areas can provide invaluable information in the study of the potential risk for humans and animals.

In the literature, the portion of chemical elements' total content in an earth material that can be liberated to the surface environment and the biosphere through mechanical, chemical or biological processes, is defined as their geoavailability (Smith and Huyck 1999). This portion is related to the susceptibility and availability of elemental resident mineral phases to alteration and weathering reactions, thus contaminating the surface environment. Geochemical studies based on bulk analysis and sequential extraction tests have been used in several occasions in relevant sediment and soil pollution studies (Tessier et al. 1979, Pickering 1998, Li and Thornton 2001). Mineralogical studies utilising XRD and SEM is another approach for polluted soil characterization (Davis et al. 1993, Camm et al. 2003). However a combined geochemical and mineralogical approach in the study of the resident phases in soil and sulphide mine tailings is addressed by only few authors in the literature (Adamo et al. 1996, Adamo et al. 2002, Boulet and Larocque 1998). This paper presents the findings of research on geochemical and mineralogical characterization of garden soil, with the aim to contribute further to the understanding of processes controlling elemental release within the surface environment in the mining village of Stratoni in North Greece. 


\section{Materials and Methods}

\subsection{Soil Sampling and Sample Preparation}

Detailed sampling and analysis were undertaken as part of an MSc dissertation project (Plakaki 2006). Thirty eight surface soil samples were collected from a total area of $0.7 \mathrm{~km}^{2}$ within an industrial area of mining and processing of sulphide ore, the village of Stratoni in Chalkidiki peninsula, North Greece (Perantonis 1994). The wider area is characterized by extensive mixed sulphide mineralization (Nebel et al. 1991, Perantonis 1994).

The total residential area was divided into strata based on building blocks, according to a stratified random sampling design. One house was randomly selected inside each stratum and one soil sample was collected from the garden (Fig. 1). Samples were also collected from communal, recreational areas within the settlement as well as from the primary school and the kindergarten playgrounds. The average distance between sampling sites was $150 \mathrm{~m}$ and the selected sampling depth was $0-5 \mathrm{~cm}$. It is made clear at this point that this research was focused on the characterization of the uppermost soil layer $(0-5 \mathrm{~cm})$ as the medium the local population and especially children are directly exposed to, during outdoor activities. It is already known from previous studies (Kelepertsis et al. 1999, Kelepertsis et al. 2006) that the soil geochemistry of the wider area of Stratoni is characterized by high heavy metal concentrations even at greater sampling depths, due to the sulphide mineralization. That is why it was thought that mixing soil of deeper layers might give misleading results with respect to pollution exposure.

A hand auger was used to collect a 4-fold composite sample from an area of $1 \mathrm{~m}^{2}$ at each sampling location after removing surface vegetation, making up a field sample of $500 \mathrm{~g}$ after mixing. Nine duplicate samples were collected at random locations, $10 \mathrm{~m}$ away from the original site for estimating sampling uncertainty of the measurements (Ramsey and Argyraki 1997, Argyraki 2005). This distance represented the locational accuracy provided by the GPS instrument that was used.

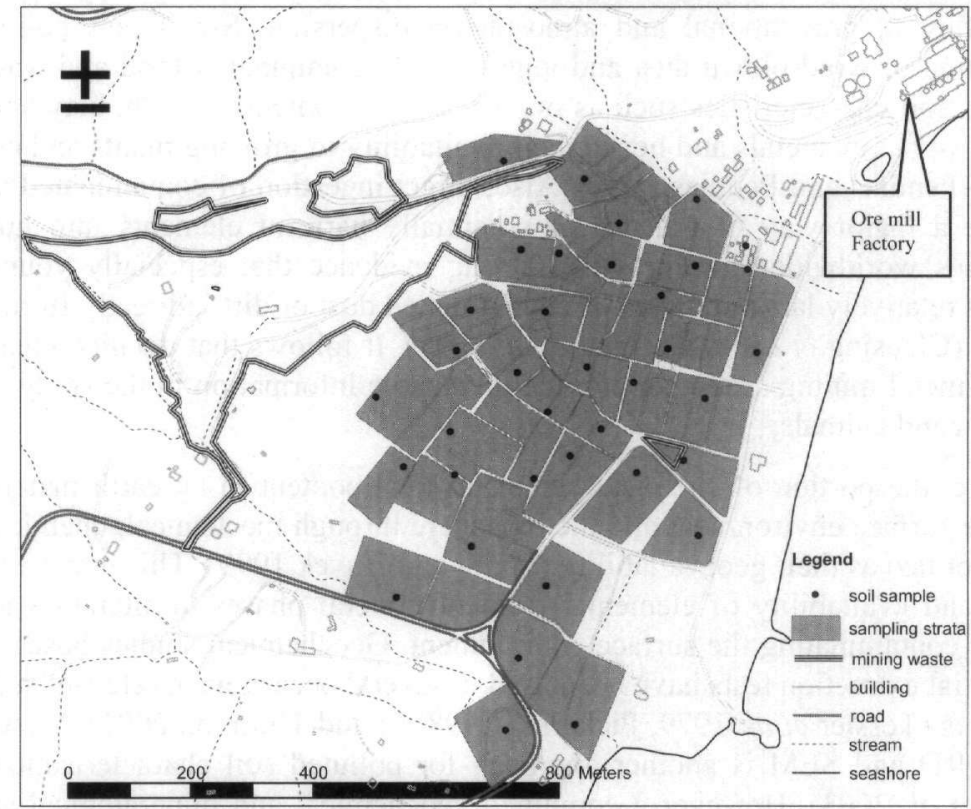

Figure 1 - Map of Stratoni village in north Greece, showing the soil sample collection points

Field soil samples were carried to the laboratory in plastic bags and were prepared for chemical analysis by drying at a temperature of $40{ }^{\circ} \mathrm{C}$, disaggregating, sieving by a $2 \mathrm{~mm}$ plastic sieve, grinding with automatic mill in an agate mortar and final sieving to pass through a $100 \mu \mathrm{m}$ sieve, 
thus producing the laboratory sample. All utensils that were used were thoroughly cleaned between the samples in order to avoid cross contamination.

\subsection{Analytical Procedures}

\subsubsection{Chemical Analysis}

Concentrations of $\mathrm{Pb}, \mathrm{Zn}, \mathrm{Cu}, \mathrm{Cd}, \mathrm{Mn}$ and $\mathrm{Fe}$ in soil samples were measured by Perkin Elmer 1100B AAS at the laboratory of Economic Geology and Geochemistry, University of Athens after total dissolution of $500 \mathrm{mg}$ soil with a mixture of $\mathrm{HF}, \mathrm{HClO}_{4}$ and $\mathrm{HNO}_{3}$ acids.

After determining the total content of metals, a sequential extraction with 5 steps (Tessier et al. 1979, Li et al. 2001) was carried out on 10 samples selected on a basis of total metal content and sample location. The method examines the possible "operationally defined" geochemical phases of metals in overburden materials including metallurgical processing wastes and residual or alluvial contaminated soil. Extraction was carried out progressively on an initial weight of $1 \mathrm{~g}$ of test material. The chemicals used and operationally defined chemical fractions are outlined below:

- Fraction 1: exchangeable (exchangeable phase) - sample extracted with magnesium chloride at $\mathrm{pH} 7$.

- Fraction 2: bound to carbonate and specifically adsorbed (carbonate phase) - residue extracted with sodium acetate at $\mathrm{pH} 5$.

- Fraction 3: bound to Fe-Mn oxides (reducible phase) - residue extracted with hydroxylammonium hydrochloride.

- Fraction 4: bound to organic matter and sulphide (oxidisable phase) - residue extracted with nitric acid, hydrogen peroxide and ammonium acetate.

- Fraction 5: residual phase - residue digested with concentrated nitric, perchloric and hydrofluoric acids.

Analar ${ }^{\circledR}$ - grade chemicals and deionised water were used throughout the analysis. All glass laboratory utensils were washed with a detergent, then soaked for 24 hours in $5 \% \mathrm{HNO}_{3}$ acid solution and rinsed repeatedly with deionised water. Reference materials, duplicates and reagent blanks were distributed at random throughout the whole extraction procedures to make the most realistic assessments of data quality. Three international certified reference materials by NIST (SRM2709, SRM2710 and SRM2711) were used for estimating analytical bias and 18 analytical duplicates were used for estimating analytical precision.

The significant parameter of soil $\mathrm{pH}$ was determined after mixing soil with deionised water and organic carbon content was determined by titration with $\mathrm{K}_{2} \mathrm{Cr}_{2} \mathrm{O}_{7}$ in an acid environment.

\subsubsection{Mineralogical Analysis and Microanalytical Method}

Mineralogical determination was performed on the high density ( $\mathrm{SG}>2.96$ ) fraction of selected soil samples, after gravity separation in tetrabromoethane. A Siemens D-500 instrument was used for XRD analysis. Scanning Electron Microscopy and EDS analysis were carried out on resin impregnated/ carbon coated samples, using a Jeol JSM 5600 SEM instrument, equipped with an Oxford ISIS 300 micro analytical device. Examination in the backscattered electron (BSE) mode permitted the localisation of areas where heavy metals were concentrated. All analysis was performed in the facilities of Faculty of Geology and Geoenvironment, University of Athens. 


\section{Results and Discussion}

\subsection{Total Concentration of Heavy Metals in Soil}

Quality control on measurements of total concentrations yielded acceptable results for most studied heavy metals. Analytical bias was estimated within $\pm 10 \%$ of the certified value, and analytical precision was better than $\pm 5 \%$ of mean value for a $2 \mathrm{~s}$ interval. In exception to the above, analytical precision for $\mathrm{Fe}$ reached $\pm 14 \%$ probably due to volumetric errors and precision of $\mathrm{Cd}$ was $\pm 30 \%$ probably due to low concentration readings near the detection limit of the method.

The descriptive statistics of total concentrations of the studied elements are presented in Table 2.

Table 2 - Descriptive statistics of geochemical parameters measured in soil. Total concentration of heavy metals in soil in $\mu \mathrm{g} \mathrm{g}^{-1}(\mathrm{n}=38)$. Organic $\mathrm{C}$ in $\%(n=10)$

\begin{tabular}{|c|c|c|c|c|c|}
\hline Element & Mean & Median & $\begin{array}{c}\text { Standard } \\
\text { deviation }\end{array}$ & Min & Max \\
\hline $\mathrm{Pb}$ & 1090 & 1071 & 390 & 124 & 2042 \\
\hline $\mathrm{Zn}$ & 878 & 712 & 569 & 133 & 2520 \\
\hline $\mathrm{Cu}$ & 184 & 184 & 50 & 45 & 285 \\
\hline $\mathrm{Cd}$ & 6 & 6 & 3 & 2 & 15 \\
\hline $\mathrm{Fe}$ & 45700 & 45103 & 9205 & 23786 & 73767 \\
\hline $\mathrm{Mn}$ & 4465 & 2940 & 4368 & 394 & 19777 \\
\hline $\mathrm{pH}$ & 6.9 & 7.0 & 0.8 & 3.9 & 8.0 \\
\hline $\begin{array}{c}\mathrm{Org} \mathrm{C} \\
(\%)\end{array}$ & 5 & 5 & 3 & 0 & 9 \\
\hline
\end{tabular}

In Table 3 the measured concentrations are compared to the global soil mean (Levinson, 1980), estimated concentrations in soils of the wider area from a previous study (Kelepertsis et al., 2006) as well as selected international soil pollution guideline values for residential and industrial areas.

Table 3 - Comparison of measured concentrations of heavy metals in soil, with selected international guideline limits in $\mu \mathrm{g} \mathrm{g}^{-1}$

\begin{tabular}{|c|c|c|c|c|c|c|c|c|}
\hline \multirow{2}{*}{ Element } & \multirow{2}{*}{ Mean } & \multirow{2}{*}{$\begin{array}{c}\text { Global } \\
\text { soil } \\
\text { mean }^{1}\end{array}$} & \multirow{2}{*}{$\begin{array}{c}\text { Wider } \\
\text { area } \\
\text { soil mean }\end{array}$} & \multicolumn{2}{|c|}{$\begin{array}{c}\text { G. Britain } \\
(\mathrm{DOE}-\mathrm{ICRCL})^{3}\end{array}$} & \multirow{2}{*}{$\begin{array}{c}\text { France }^{4} \\
\text { Clean-up }\end{array}$} & \multirow{2}{*}{$\begin{array}{c}\text { Canada }^{5} \\
\begin{array}{c}\text { Industrial } \\
\text { use limit }\end{array}\end{array}$} & \multirow{2}{*}{$\begin{array}{c}\text { USA }^{6} \\
\text { Clean -up }\end{array}$} \\
\hline & & & & $\begin{array}{l}\text { Small } \\
\text { garden }\end{array}$ & $\begin{array}{l}\text { Open } \\
\text { space }\end{array}$ & & & \\
\hline $\mathrm{Pb}$ & 1090 & 17 & 895 & 550 & 1500 & 1000 & 1000 & 400 \\
\hline $\mathrm{Zn}$ & 878 & 50 & 654 & 280 & $280-560$ & 3000 & 1500 & - \\
\hline $\mathrm{Cu}$ & 184 & 20 & 150 & 140 & $140-280$ & 1000 & 500 & 600 \\
\hline $\mathrm{Cd}$ & 6 & 1 & 3 & 5 & $12-15$ & 20 & 20 & 39 \\
\hline $\mathrm{Fe}$ & 45700 & 35000 & 61160 & - & - & - & - & - \\
\hline $\mathrm{Mn}$ & 4465 & 530 & 3037 & - & - & 10000 & - & - \\
\hline
\end{tabular}

${ }^{1}$ Levinson, 1980, ${ }^{2}$ Kelepertsis et al., 2006, ${ }^{3}$ ICRCL, 1990, ${ }^{4}$ CCME, 1992, ${ }^{5}$ ASTM, 1995, ${ }^{6}$ New Jersey DOE, 1999

The data show elevated concentrations of all studied elements, well above the global soil mean but also higher than the mean concentrations in soils from the wider area. Specifically, $\mathrm{Pb}$ with a mean value of $1090 \mu \mathrm{g} \mathrm{g}^{-1}$ is very close to the maximum concentration limit for industrial areas and exceeds the concentration limit for small gardens by a factor of 2 . Average concentrations of $\mathrm{Zn}$, 
$\mathrm{Cu}$ and $\mathrm{Cd}$ are $878 \mu \mathrm{g} \mathrm{g}^{-1}, 184 \mu \mathrm{g} \mathrm{g}^{-1}$ and $6 \mu \mathrm{g} \mathrm{g}^{-1}$ respectively, exceeding concentration limits for small gardens but conforming the limits for areas of industrial use according to Canadian standards. Iron and $\mathrm{Mn}$ are elements of less environmental concern in respect with health hazard, nevertheless they demonstrate mean concentrations of $5 \%$ and $4465 \mu \mathrm{g} \mathrm{g}^{-1}$ respectively, which are higher than the estimated means in the wider area.

Significantly high positive correlation coefficients were observed between $\mathrm{Zn}$ and $\mathrm{Cd}(>0.9), \mathrm{Mn}$ and $\mathrm{Pb}>\mathrm{Cd}(>0.7), \mathrm{Pb}$ and $\mathrm{Cd}>\mathrm{Cu}>\mathrm{Zn}(>0.5), \mathrm{Cu}$ and $\mathrm{Fe}>$ organic carbon $(>0.6)$. The high correlation between the elements indicates common origin and can be attributed to presence of metallic minerals and their weathering products in surface soil. The high correlation between organic carbon and $\mathrm{Cu}$ shows the significant role of organic matter in the speciation of this element. Soil $\mathrm{pH}$ was measured between 3.9 and 8.0 with a mean value of 6.9. It is well known that in the surface environment with abundant oxygen, heavy metals tend to precipitate from solutions, forming solid phases under neutral- alkaline $\mathrm{pH}$ conditions (Smith and Huyck 1999). The $\mathrm{pH}$ data of this study signify in deed environmental conditions that favour precipitation of metals in solid phases.

\subsection{Partition of Heavy Metals in Operationally Defined Solid Phases}

The analytical results of the sequential extraction procedure demonstrated precision between $\pm 2 \%$ and $20 \%$ for all elements and all extraction steps. Analytical bias, estimated by analysis of the NIST certified reference materials was also found to be within acceptable limits except for Fe. The data were subsequently processed within their stated uncertainties.

Figure 4 presents the proportion (\%) of each metal in each one of the 5 operationally defined phases. These phases differ in respect with potential availability of elements into the environment and include in order of decreasing availability (Tessier et al. 1979): (a) the exchangeable phase, i.e. the fraction of metals adsorbed in exchange sites on surfaces of clays and colloids; (b) the carbonate phase, i.e. the metal fraction associated with carbonate minerals and metals specifically adsorbed on surfaces of amorphous precipitates of Fe, Al, Mn oxides/ hydroxides and phosphates; (c) the reducible phase comprising metals associated with $\mathrm{Mn}$ and $\mathrm{Fe}$ oxides through coprecipitation and binding within the oxide structure; (d) the oxidisable phase, i.e. the fraction of metals bound to soil organic matter and metals incorporated in the structure of sulphide minerals and (e) the residual phase including elements incorporated in the crystal lattice of silicate minerals and vitreous metallurgical phases such as slag.

The data of sequential extraction soil analysis in this study show that the fractionation of studied heavy metals varies. This observation has significant implications on the potential bioavailability of metals, thus their potential risk for human and animal health. Specifically, $\mathrm{Pb}$ is fractioned mainly $(53 \%)$ in the residual phase of relatively insoluble soil components as well as the reducible phase of Fe-Mn oxides (40\%) which also represent stable solid phases. On the contrary, $\mathrm{Zn}, \mathrm{Cd}$ and $\mathrm{Mn}$ appear in the residual phase in lower concentration, fractioned by $25 \%, 23 \%$ and $5 \%$ respectively. These elements have noticeable share in the first two easily extractable extraction steps (5- $25 \%$ ). Manganese is extracted by $90 \%$ in the reducible phase, while $\mathrm{Cu}$ appears in great proportion $(40 \%)$ in the oxidisable phase, probably indicating the significant role of organic matter as a bounding factor for this element. Iron is fractioned mainly in the reducible phase $(45 \%)$ and in the oxidisable phase of sulphides and organic matter $(30 \%)$.

Table 5 presents the most significant correlation coefficients of the metals and organic carbon in the sequential extraction fractions. These coefficients provide evidence about the most significant factors affecting speciation of metals in soil. It is observed that organic carbon, which is a significant component of surface garden soil, correlates very well with most studied elements in the oxidisable phase. Zinc and Cd are highly correlated in all extraction stages indicating the common origin of these elements from sphalerite. Correlation of $\mathrm{Zn}, \mathrm{Cd}$ and $\mathrm{Mn}$ in fractions I, II and III indicates the association of these elements with easily extractable phases, suggesting 


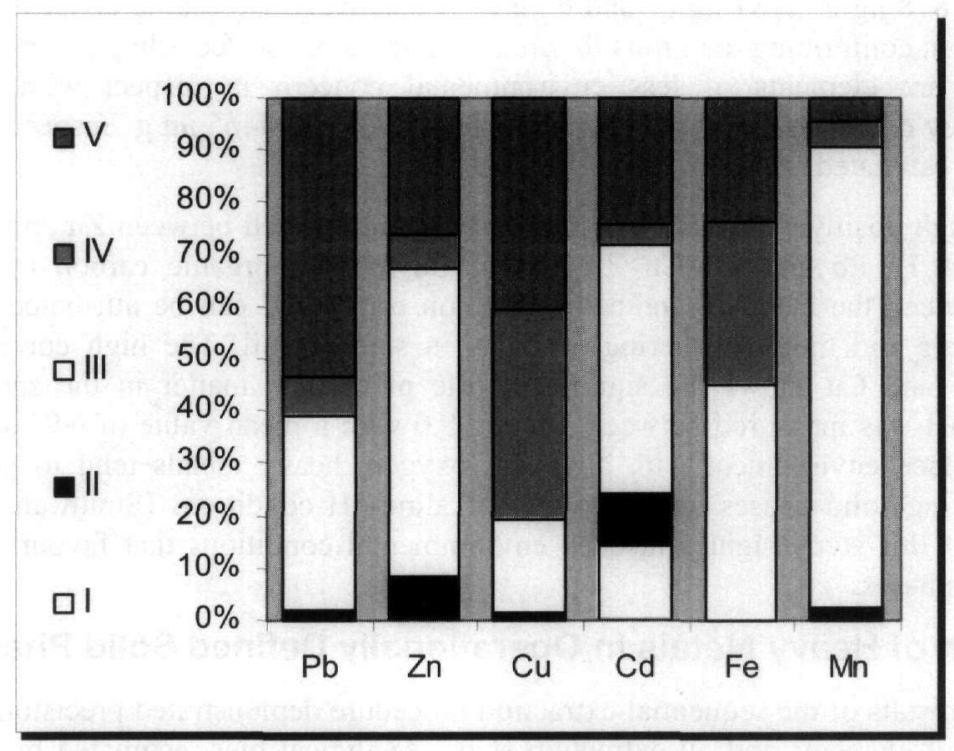

Figure 4 - Partition (\%) of heavy metals in 5 operationally defined soil phases $(n=10)$. (I):exchangeable, (II): carbonate and specifically adsorbed, (III): reducible, (IV): oxidisable, (V): residual

Table 5 - Significant correlation coefficients in the 5 steps of sequential extraction. (OC: organic carbon)

\begin{tabular}{|c|c|c|c|c|c|}
\hline Parameter & $\begin{array}{c}\text { Fraction I } \\
\text { Exchangeable }\end{array}$ & $\begin{array}{c}\text { Fraction II } \\
\text { Specifically } \\
\text { adsorbed }\end{array}$ & $\begin{array}{c}\text { Fraction III } \\
\text { Reducible }\end{array}$ & $\begin{array}{c}\text { Fraction IV } \\
\text { Oxidisable }\end{array}$ & $\begin{array}{c}\text { Fraction V } \\
\text { Residual }\end{array}$ \\
\hline $\mathrm{Cu} / \mathrm{OC}$ & & & & 0.74 & 0.61 \\
\hline $\mathrm{Zn} / \mathrm{OC}$ & & & & 0.55 & \\
\hline $\mathrm{Cd} / \mathrm{OC}$ & & & & 0.58 & \\
\hline $\mathrm{Fe} / \mathrm{OC}$ & 0.64 & & & 0.79 & \\
\hline $\mathrm{Mn} / \mathrm{OC}$ & & 0.71 & & & \\
\hline $\mathrm{Pb} / \mathrm{Fe}$ & & & 0.65 & & 0.60 \\
\hline $\mathrm{Cu} / \mathrm{Fe}$ & 0.83 & & & 0.81 & \\
\hline $\mathrm{Cd} / \mathrm{Fe}$ & & & & 0.77 & 0.56 \\
\hline $\mathrm{Pb} / \mathrm{Mn}$ & & & & & \\
\hline $\mathrm{Cu} / \mathrm{Mn}$ & 0.52 & & & & \\
\hline $\mathrm{Zn} / \mathrm{Mn}$ & 0.52 & 0.78 & 0.64 & 0.72 & \\
\hline $\mathrm{Cd} / \mathrm{Mn}$ & & 0.64 & 0.86 & & 0.64 \\
\hline $\mathrm{Fe} / \mathrm{Mn}$ & 0.59 & & & & \\
\hline $\mathrm{Zn} / \mathrm{Cd}$ & 0.96 & 0.96 & 0.93 & 0.86 & 0.95 \\
\hline
\end{tabular}

increased mobility in the environment. Lead is correlated with $\mathrm{Fe}$ in the residual phase possibly indicating the coexistence of the two elements in metallurgical slag grains in soil.

\subsection{Mineralogical Data and Microanalysis}

Identified minerals with XRD analysis comprise mainly (95\%) common soil inorganic phases such as quartz, feldspar, mica and the clay minerals kaolinite and illite. Sulphide minerals such as sphalerite and insoluble weathering products containing heavy metals such as alunite and tsumcorite were also recorded in the diffraction spectra. SEM-EDS observations and microanalysis re- 
sults indicated that the studied material is rich in quartz $>$ feldspar $>$ mica and clays $>$ Fe-Mn oxides $>$ sulphide minerals.

Microanalysis of selected bright particles in back-scattered mode indicated presence of secondary minerals of very low solubility, enriched in heavy metals, particularly $\mathrm{Pb}$ (Fig. 6). Specifically, the lead-phosphate mineral pyromorphite $(\log K s p=-84.4)$ has been identified in several grains. Also, the practically insoluble mineral corkite $(\log K s p=-112.6)$, which is a Pb-rich member of the alunite supergroup (Jambor 2000) was identified. The exact chemical composition of identified corkite in the studied samples is presented on a phosphorus- sulfur- arsenic ternary diagram in Figure 7. Abundant $\mathrm{Fe}$ and $\mathrm{Mn}$ oxides and oxy-hydroxides, enriched in heavy metals were also found by SEM-EDS in agreement with the sequential extraction results. Sulphide grains corresponding to the primary mineralization of the wider area were also identified including galena, sphalerite, arsenopyrite and pyrite. The latter, often appears oxidised, forming pseudomorph crystals. Finally, anthropogenic grains of weathered metallurgical slag were observed. The composition of such grains is characterized by a $\mathrm{Si}-\mathrm{Fe}$ - $\mathrm{Ca}$ vitreous phase, enriched in heavy metals. In many instances, slag grains appear weathered with pyromorphite precipitates on their periphery.
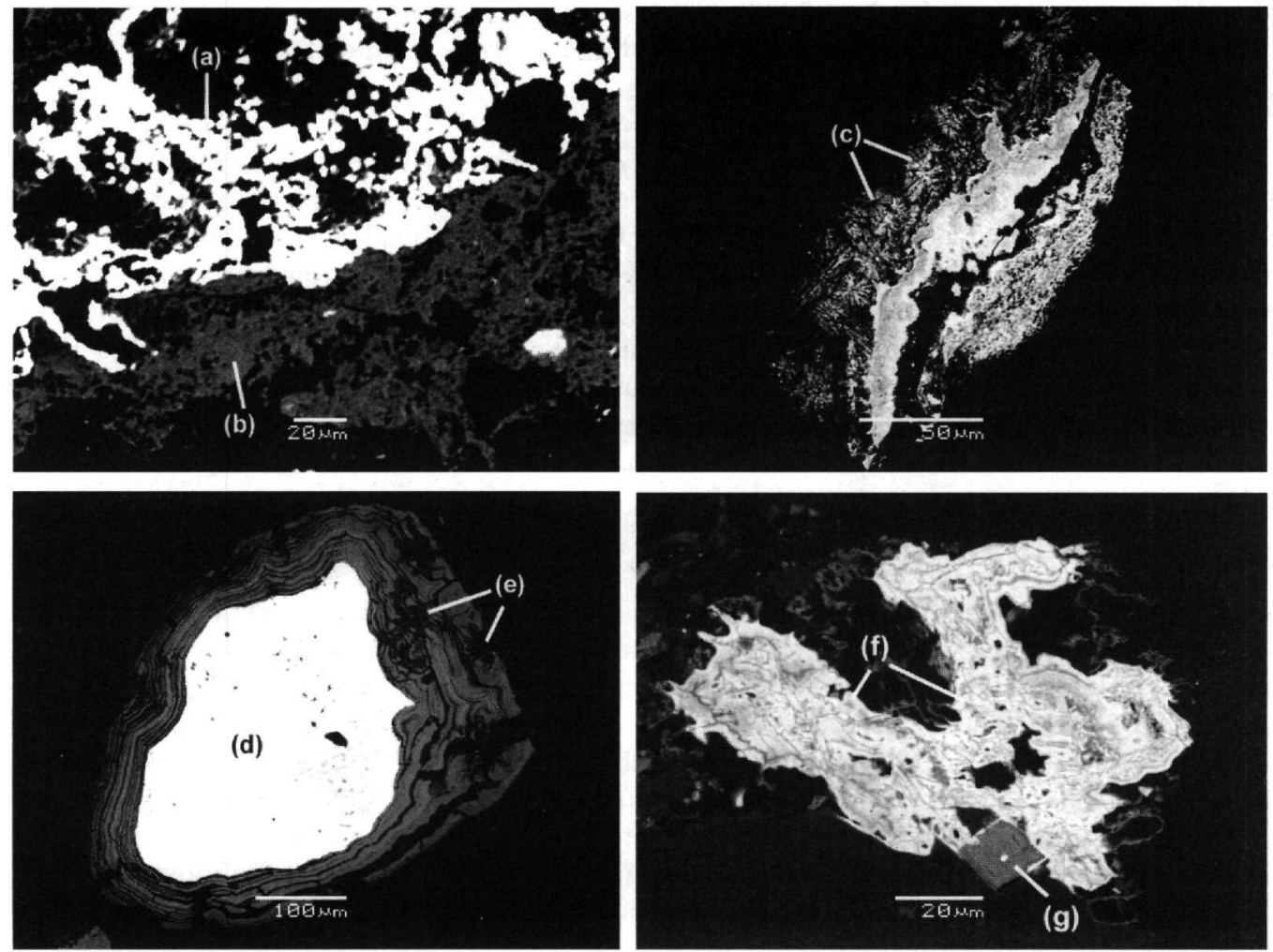

Figure 6 - SEMs in back-scattered mode of selected bright particles: (a) Pb- alunite (corcite), (b) jarosite, (c) pyromorphite, (d) metallurgical slag containing $\mathrm{Si}, \mathrm{Fe}, \mathrm{Pb}$, (e) pyromorphite, (f) Fe-Mn oxide enriched in heavy metals, (g) oxidised pyrite pseudomorph

\subsection{Mobility of Heavy Metals in Surface Soil}

The combined results of total chemical analysis, sequential extraction, mineralogical analysis and microanalysis were used to indirectly assess the potential mobility and bioavailability of metals in garden soil. 

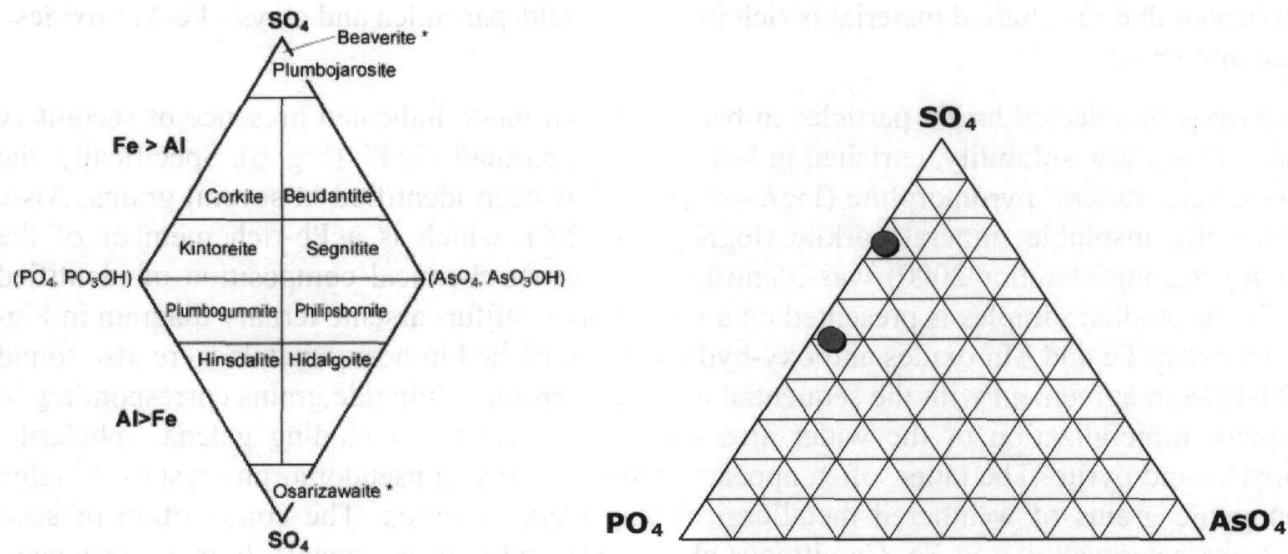

Figure 7 - Phosphorus- sulfur- arsenic double ternary diagram showing mineral species of the alunite supergroup (Jambor, 2000). Circles on ternary diagram on the right indicate microanalytical results of this study corresponding to corcite composition $(\log K s p=\mathbf{- 1 1 2 . 6})$

\subsubsection{Lead}

Lead has high mean total concentration of $1090 \mu \mathrm{g} \mathrm{g}^{-1}$ in soil. However, according to sequential extraction data, this element is fractioned mostly $(53 \%)$ in the residual phase of less soluble soil components. Microanalytical SEM results indicate that $\mathrm{Pb}$ is abundant in anthropogenic phases (metallurgical slag) as well as natural phases of very low solubility (pyromorphite, alunite, tsumcorite). It seems that physicochemical conditions of soil in the study area, favour precipitation of such phases, thus limiting the potential mobility and bioavailability of $\mathrm{Pb}$. The element is also associated with Fe-Mn oxide phases, which are abundant in the surface soil environment and act as scavengers of the metal. In the oxidizing surface environment oxides are considered to be very stable. Lead in the studied samples is also associated to a lesser extent with sulphide phases, i.e. galena.

\subsubsection{Zinc}

Sequential extraction data indicate that $\mathrm{Zn}$ with a total concentration of $878 \mu \mathrm{g} \mathrm{g}^{-1}$ is primarily associated with Fe-Mn oxides (60\%) which seem to be effective scavengers for this element in surface soil. Indeed, SEM-EDS observations confined $\mathrm{Zn}$ within Fe-Mn oxi-hydroxide phases together with other potentially toxic elements such as $\mathrm{Pb}$ and $\mathrm{As} .25 \%$ of $\mathrm{Zn}$ was fractioned in the residual phase of the sequential extraction, probably reflecting the high content of this element in the metallurgical slag grains. Only $6.5 \%$ of the element was fractioned in the oxidisable phase of sulphides and organic matter, while $8 \%$ was determined as specifically adsorbed on surfaces of solid soil phases. In general, this element appears to be more mobile than $\mathrm{Pb}$, however its total concentration combined with its fractionation data do not raise serious concerns about its potential threat for the living environment.

\subsubsection{Copper}

Copper was fractioned mainly in residual phase ( $40 \%)$ and oxidisable phase $(40 \%)$ of the sequential extraction. In the studied samples it showed a strong correlation with $\mathrm{Fe}$ and organic carbon while SEM-EDS analysis indicated its association with Fe-Mn oxides. These observations as well as the fact that $\mathrm{Cu}$ is not a characteristic element of the primary mineralization of the area and its total concentration in soil is not extremely high $\left(184 \mu \mathrm{g} \mathrm{g}^{-1}\right)$, provide no evidence of increased risk for the local environment. Anthropogenic sources of $\mathrm{Cu}$ are also expected to contribute to this element's distribution in surface garden soil through application of $\mathrm{CuSO}_{4}$ as a pesticide. However additional work is needed in order to clarify which is the exact form of $\mathrm{Cu}$ in soil and particularly the type of the element's bonding with soil organic matter. 


\subsubsection{Cadmium}

The average concentration value of cadmium in soil was estimated at $6 \mu \mathrm{g} \mathrm{g}^{-1}$, however poor analytical precision of $\pm 30 \%$ contributes to increased uncertainty when interpreting the geochemical data for this element. The high correlation coefficient between $\mathrm{Cd}$ and $\mathrm{Zn}$ in those samples containing substantial amounts of $\mathrm{Cd}$, indicates common origin of the two elements from sphalerite, in spite the fact that no Cd was found by SEM-EDS microanalysis. The sequential extraction results indicated that $\mathrm{Cd}$ is associated with easily extractable phases of the $1^{\text {st }}$ step, i.e. $\mathrm{Cd}$ ions are loosely adsorbed on surfaces of solid phases in soil. This observation signifies increased mobility and possible enhanced bioavailability of the specific element.

\subsubsection{Iron}

Volumetric errors possibly contributed to increased uncertainty on Fe concentrations in this research. Nevertheless, the results demonstrated the significant role of this element as a controlling factor for the distribution and mobility of the other studied elements, mainly through the scavenging properties of formed Fe-oxides in soil. Studied soils are rich in Fe (mean concentration of $4.6 \%$ ). The element was fractioned in the reducible phase of sequential extraction procedure by $45 \%$, the oxidisable phase by $30 \%$ and the residual phase by $25 \%$.

\subsubsection{Manganese}

Manganese does not pose a great health threat however, like Fe has an important role in controlling the mobility of other elements. $90 \%$ of the total Mn soil content $\left(4465 \mu \mathrm{g} \mathrm{g}^{-1}\right)$ in this study was fractioned in the reducible phase. This result agrees with SEM-EDS data where Fe-Mn oxides were observed as dominant soil phases, attracting heavy metals. Also the sequential extraction data indicated a good correlation between $\mathrm{Mn}-\mathrm{Zn}-\mathrm{Cd}$ in the $1^{\text {st }}$ three extraction steps indicating that $\mathrm{Mn}$ is relatively mobile in this particular soil environment.

\section{Conclusions}

The combination of geochemical and mineralogical data has been applied successfully in the characterization of surface soil within the Stratoni mining village environment. The applied methodology gave useful information with respect to the potential risk for the environment imposed by heavy metals in soil, which would not be available if only the total concentrations of heavy metals were measured. Specifically, sequential extraction results coupled by SEM-EDS microanalysis data indicated variety of solid phases withholding the metals, thus differentiation of metal mobility/ availability in the study area. Lead has high mean concentration but is fractioned mostly in the residual phase of less soluble soil components limiting its potential bioavailability while $\mathrm{Zn}, \mathrm{Cd}$ and $\mathrm{Mn}$, participate in appreciable proportion in easily extractable phases indicating easy mobilization and greater potential bioavailability. The output of the research can be used in conjunction with other relevant information for risk assessment and for selecting appropriate remediation measurements in the area.

\section{Acknowledgments}

The authors would like to thank Dr. V. Gazea of Hellas Gold for the provision of digital maps of Stratoni village and the useful discussions during this research. Also the local authorities and people living in Stratoni for permitting soil sampling in their gardens. This project was financially supported by the National \& Kapodistrian University of Athens - Special Account for Research Grand 70/4/7624 - Programme "Kapodistrias" (2004-2005).

\section{References}

Abrahams, P.W., and Steigmajer, J., 2003. Soil ingestion by sheep grazing the metal enriched floodplain soils of Mid-Wales, Environmental Geochemistry and Health, 25, 17-24. 
Adamo, P., Dudka, S., Wilson, M.J., and McHardy, W.J., 1996. Chemical and mineralogical forms of $\mathrm{Cu}$ and $\mathrm{Ni}$ in contaminated soils from the Sudbury mining and smelting region, Canada, Environmental Pollution, 91, 11-19.

Adamo, P., Dudka, S., Wilson, M.J., and McHardy, W.J., 2002. Distribution of trace elements in soils from the Sudbury smelting area (Ontario, Canada), Water, Air and Soil Pollution, 137, 95-116.

Appleton, J.D., 1995. Potentially harmful elements from natural sources and mining areas: characteristics, extent and relevance to planning and development in Great Britain, Technical Report WP/95/3, Keyworth Nottingham, British Geological Survey, 63pp.

Argyraki, A., 2005. Methods for estimating measurement uncertainty from sampling in environmental geochemistry soil investigations, Proc. of $1^{\text {st }}$ National Conference on Metrology, Athens, 11-12 November, 184- 193. (in Greek)

Boulet, M.P., and Larocque, A.C.L., 1998. A comparative mineralogical and geochemical study of sulfide mine tailings at two sites in New Mexico, USA, Environmental Geology, 33, 130142 .

Camm, G., Butcher, A., Pirrie, D., Hughes, P., and Glass, H., 2003. Secondary mineral phases associated with a historic arsenic calciner identified using automated scanning electron microscopy; a pilot study from Cornwall, UK, Minerals Engineering, 16, 1269- 1277.

Clausing, P., Brunekereef, B., and van Wijnen, J.H., 1987. A method for estimating soil ingestion by children, International Archives of Occupational and Environmental Health, 59, 73-82.

Davis, A., Drexier, J., Ruby, M., and Nicholson A., 1993. Microminerology of Mine Wastes in Relation to Lead Biovailability, Butte, Montana, Environmental Science \& Technology, 27. 1415- 1425.

Jambor, J., 2000. Nomenclature of the Alunite supergroup - Reply, The Canadian Mineralogist. $38,298-1303$.

Kabata-Pendias, A., and Pendias, H., 1984. Trace Elements in Soils and Plants, Boca Raton Florida, CRC Press Inc., 315- 333pp.

Kelepertsis, A., Argyraki, A., and Alexakis, D., 2006. Multivariate statistics and spatial interpretation of geochemical data for assessing soil contamination by toxic metals in the mining area of Stratoni, North Greece, Geochemistry: Exploration, Environment, Analysis, 6, 349-355.

Kelepertsis, A., Karvounis, G., and Zotiadis, V., 1999. Evaluation of soil quality in the wider area of Stratoni, Unpublished Technical Report, University of Athens. (in Greek)

Kelepertsis, A., and Bibou, A., 1991. Heavy metal contamination of soils at old mining sites on Thassos Island, Greece, Environmental Geochemistry and Health, 13, 23-28.

Levinson, A.A., 1980. Introduction to Exploration Geochemistry $2^{\text {nd }}$ Edition - the 1980 Supplement, Wilmette Illinois, Applied Publishing, 924pp.

Li, X., and Thornton, I., 2001. Chemical partitioning of trace and major elements in soils contaminated by mining and smelting activities, Applied Geochemistry, 16, 1693-1706.

Nebel, M., Hutcinsin, R., and Zartman, R., 1991. Metamorphism and polygenesis of the Madem Lakkos polymetalic sulphide deposit, Chalkidiki, Greece, Economic Geology, 86, 81-105.

Perantonis, G., 1994. Mixed sulphides of Kassandra Mines at M. Lakkos and Olympias, Proc. of One-Day Symposium on Mineral Wealth of Chalkidiki and the environment, Chalkidiki 13 May, 113-126. (in Greek) 
Pickering, W.F., 1998. Metal ion speciation - soils and sediments, Ore Geology Reviews, 1, 83146.

Plakaki, A., 2006. Mobility of potentially toxic elements in soils of the Stratoni mining area, Chalkidiki, N. Greece, MSc Dissertation, University of Athens. (in Greek)

Ramsey, M.H., and Argyraki, A., 1997. Estimation of measurement uncertainty from field sampling: implication for the classification of contaminated land, The Science of the Total Environment, 198, 243-257.

Smith, K.S., and Huyck, L.O., 1999. An overview of the abundance, relative mobility, biovailability and Human Toxicity of Metals. In G.S. Plumlee and M.J. Longdon (eds), The Environmental Geochemistry of Mineral Deposits, Reviews in Economic Geology: Society of Economic Geologists, v. 6A, 29-66pp.

Tessier, A., Campbell, P.G.C., and Bisson, M., 1979. Sequential extraction procedure for speciation of particulate trace metals, Analytical Chemistry, 51, 844-851.

Thornton, I., 1993. Environmental Geochemistry and Health in the 1990s: a global perspective, Applied Geochemistry Supplement, 2, 203-210.

Vardaki, C., and Kelepertsis, A., 1999. Environmental impact of heavy metals (Fe, Ni, Cr, Co) in soils, waters and plants of Triada in Euboea from ultrabasic rocks and nickeliferous mineralisation, Environmental Geochemistry and Health, 21, 211-226.

Watt, J., Thornton, I., and Cotter-Howells, J., 1993. Physical evidence suggesting the transfer of soil into young children via hand-mouth activity, Applied Geochemistry, Supplement No. 2, 269-272. 